dr Zbigniew Gruszka

Uniwersytet Łódzki

Katedra Informatologii i Bibliologii

zgruszka@uni.lodz.pl

\title{
BUDŻET OBYWATELSKI A BIBLIOTEKA PUBLICZNA. ANALIZA WNIOSKÓW NA PRZYKŁADZIE ŁODZI
}

\author{
A PARTICIPATORY BUdGeT AND A PUBLIC LIBRARY. \\ The ANAlysis OF THE APPLICATIONS ON THE EXAMPLE OF LóDź
}

\begin{abstract}
Abstrakt
W pracy przeanalizowano i omówiono zgłoszone do łódzkiego budżetu obywatelskiego wnioski dotyczące lokalnych bibliotek publicznych w ostatnich pięciu edycjach - ich liczbę, skuteczność pozyskiwania środków partycypacyjnych oraz przyznane kwoty. W gromadzeniu danych zastosowano metodę analizy dokumentów. Na wybranych przykładach zostały przedstawione zarówno zadania skierowane do realizacji, jak i niezakwalifikowane. Przedstawiono też ocenę idei budżetu obywatelskiego jako formy wsparcia finansowego bibliotekarstwa publicznego.
\end{abstract}

Słowa kluczowe: budżet obywatelski, bibliotekarstwo publiczne, Łódź.

\begin{abstract}
The author analysed the library applications submitted to the Lodz participatory budget, which is a form of a financial support for the public librarianship. There was the information provided on the presence of the library applications in the last five editions - their number, the effectiveness of acquiring participation resources and the amounts awarded. During data collecting, the method of document analysis was used. Both the accepted and the unqualified applications were shown on the selected examples.
\end{abstract}

Keywords: participatory budget, public librarianship, Łódź. 


\section{Wstęp}

W ostatnich latach daje się zaobserwować w Polsce rosnące zainteresowanie władz samorządowych uchwalaniem budżetów obywatelskich. Partycypacyjne dysponowanie środkami publicznymi wprowadziły m.in.: Dąbrowa Górnicza, Elbląg, Łódź, Płock, Poznań, Toruń i Warszawa ${ }^{1}$. Po 2013 r. dołączyły m.in.: Gdańsk, Olsztyn, Częstochowa, a także liczne mniejsze miejscowości, jak np.: Kutno, Głogów, Racibórz.

Budżet obywatelski to wydzielona część budżetu miasta, o której przeznaczeniu mogą decydować mieszkańcy ${ }^{2}$. W wyniku głosowania przyznane kwoty są następnie dopisywane jako kolejna pozycja w corocznym budżecie miasta i przeznaczane na przedmiotowe zadanie. W literaturze przedmiotu „budżet obywatelski” bywa kojarzony z takimi pojęciami jak: „partycypacja społeczna”, „zaufanie społeczne”, „edukacja obywatelska”, „zarządzanie obywatelskie" ". Nie wchodząc w szczegółową analizę terminologiczną należy zauważyć, że wszystkie one przenoszą punkt ciężkości w decydowaniu o mieście z przedstawicieli administracji publicznej na mieszkańców, przy jednoczesnej dbałości o rozwój ich wiedzy, odpowiedzialności, kreatywności i aktywności w zmienianiu przestrzeni lokalnej. Jest to tzw. edukacja przez uczestnictwo ${ }^{4}$.

Budżet partycypacyjny stał się istotnym narzędziem finansowania lokalnych przedsięwzięć wybranych przez mieszkańców w drodze głosowania. O jego popularności świadczy fakt, że obecnie planuje się społeczne dysponowanie środkami publicznymi nie tylko wśród jednostek samorządu terytorialnego, lecz także w skali województwa ${ }^{5}$. Zgłaszane przez mieszkańców miast projekty do budżetów partycypacyjnych ułatwiają realizację

1 B. Martela: Budżet partycypacyjny w Polsce - wdrożenie i perspektywy. „Władza sądzenia" 2013, nr 2, s. 25.

2 Jak to działa? Tryb dostępu: http://budzet.dlalodzi.info/jak-to-dziala/ [7 lipca 2017].

3 M. Kalisiak-Mędelska: Partycypacja społeczna na poziomie lokalnym jako wymiar decentralizacji administracji publicznej w Polsce. Łódź 2015; K. Brzeziński: Zaufanie społeczne a zaangażowanie obywatelskie w postprzemysłowych miastach Europy Środkowo-Wschodniej. „Acta Universitatis Lodziensis. Folia Sociologica” Nr 52 (2015), s. 127146; E. Boryczka: Partycypacja społeczna. W: EkoMiasto\#Społeczeństwo: zrównoważony, inteligentny i partycypacyjny rozwój miasta. Pod red. A. Nowakowskiej, Z. Przygodzkiego, A. Rzeńcy. Łódź 2016, s. 116-136.

4 E. Boryczka: Partycypacja społeczna, dz. cyt., s. 132.

5 Na przykład budżet obywatelski samorządu województwa łódzkiego, w którym do decydowania społecznego przeznaczono $5 \mathrm{mln}$ zł. W założeniu inicjatorów, budżet ma na celu między innymi „wzmocnienie poczucia tożsamości regionalnej i przynależności do blisko 2,5 mln społeczności Ziemi Łódzkiej”. Zob. http://bo.lodzkie.pl/. 
społecznych oczekiwań stawianych jednostkom samorządu terytorialnego we wszystkich obszarach ich odpowiedzialności - by wymienić jedynie sferę infrastrukturalną, kulturalną, edukacyjną. Zgodnie $\mathrm{z}$ regulaminami, w ramach środków przeznaczonych na budżet partycypacyjny możliwa jest realizacja projektów należących wyłącznie do zadań własnych miasta, gminy lub powiatu - co oznacza, że wsparcie bibliotek jako instytucji kultury, których prowadzenie należy do zadań samorządu, jest jak najbardziej uzasadnione.

Przystępując do starania się o środki obywatelskie warto zapoznać się nie tylko z wytycznymi aplikowania o nie, lecz również z inicjatywami realizowanymi w innych miastach, a także nawiązać ściślejszą współpracę z czytelnikami (lub szerzej - mieszkańcami), starając się wysondować ich opinię i zyskać poparcie dla zgłoszonego wniosku. Wartościowym doświadczeniem może być również lektura wniosków, które nie uzyskały z różnych powodów dofinansowania.

\section{Lódzki budżet obywatelski}

W Łodzi budżet obywatelski został uruchomiony w 2013 r. Obecnie trwa jego V edycja (2017/2018). Do podziału przeznaczono $40 \mathrm{mln} \mathrm{z}$, z czego 6 mln zł na każdą z dzielnic - Bałuty, Śródmieście, Polesie, Widzew, Górna oraz 10 mln zł dla zadań o charakterze ogólnomiejskim. Maksymalna wartość zgłoszonego zadania w dzielnicy wynosi 1,5 mln zł, zaś dla zadania ogólnomiejskiego - $2 \mathrm{mln}$ zł. Czas wykonania zadania nie może przekroczyć jednego roku. Warunkiem niezbędnym zgłoszonego wniosku jest, aby jego przedmiot dotyczył obiektu zależnego od samorządu, tj. był realizowany na terenie należnym do miasta. Fakt ten stanowi jeden z czynników ocenianych na poziomie wstępnej weryfikacji, która obejmuje ponadto inne wymagania formalne. O tym, które z zadań zgłoszonych przez mieszkańców zostanie zrealizowane, decyduje głosowanie $\mathrm{w}$ formie elektronicznej lub pisemnej. W V edycji (2017/2018) głosowanie odbędzie się we wrześniu 2017 r. Za prowadzenie spraw związanych $\mathrm{z}$ budżetem obywatelskim odpowiada po stronie Urzędu Miasta Łodzi Biuro ds. Partycypacji Społecznej ${ }^{6}$. Zagadnieniem promocji idei łódzkiego budżetu obywatelskiego oraz kampanią informacyjno-edukacyjną zajmuje się z kolei Stowarzyszenie Topografie ${ }^{7}$.

6 Biuro ds. Partycypacji Społecznej. Tryb dostępu: http://bip.uml.lodz.pl/index.php?str= 158\&id=18441 [7 lipca 2017].

7 Stowarzyszenie Topografie. Tryb dostępu: www.topografie.pl [7 lipca 2017]. 
Szczegółowe instrukcje dotyczące łódzkiego budżetu obywatelskiego można odnaleźć na stronie internetowej poświęconej przedsięwzięciu: budzet. dlalodzi.info. Jej autorzy zamieścili informacje o zmianach w stosunku do poprzednich edycji, zasadach głosowania, procedurze przygotowania wniosku. Na stronie umieszczono również interaktywną mapę przedstawiającą własność miejską, na terenie, której mogą być realizowane zadania zgłoszone do budżetu obywatelskiego.

O popularności obywatelskiej formy dysponowania środkami publicznymi w Łodzi świadczy liczba złożonych w każdej z edycji wniosków. W I edycji mieszkańcy przygotowali 908 wniosków, w II - 871, w III - 531, w IV - 1572, w V - było 1131 wniosków ${ }^{8}$. Wśród wymienionych liczb odnajdujemy również wnioski dotyczące łódzkich bibliotek publicznych. Jak unaocznia tabela 1., w każdej kolejnej edycji liczba wniosków bibliotecznych zwiększa się, co można interpretować zarówno, jako oznakę wzrostu zainteresowania społecznego sprawami bibliotek, jak również jako znak rosnącej aktywności bibliotekarzy na polu pozyskiwania środków pozastatutowych.

Tabela 1. Zestawienie liczbowe wniosków dotyczących bibliotek zgłoszonych do kolejnych edycji łódzkiego budżetu obywatelskiego w latach 2013-2017

\begin{tabular}{|c|c|c|c|c|c|c|c|}
\hline Edycja & 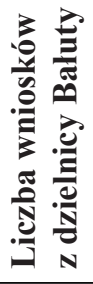 & 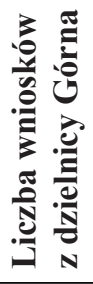 & 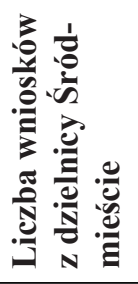 & 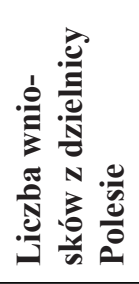 & 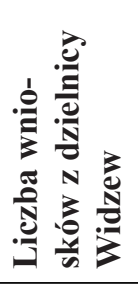 & 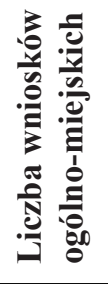 & 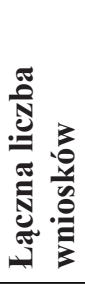 \\
\hline I edycja & 0 & 5 & 1 & 0 & 2 & 0 & 8 \\
\hline II edycja & 1 & 1 & 2 & 2 & 9 & 1 & 16 \\
\hline III edycja & 19 & 2 & 3 & 2 & 3 & 0 & 29 \\
\hline IV edycja & 9 & 16 & 9 & 8 & 12 & 1 & 55 \\
\hline V edycja & 14 & 8 & 11 & 14 & 12 & 0 & 59 \\
\hline Razem & 43 & 32 & 26 & 26 & 38 & 2 & 167 \\
\hline
\end{tabular}

Źródło: opracowanie własne na podstawie strony: Budżet dla Łodzi. Tryb dostępu: http://budzet.dlalodzi.info/ [7 lipca 2017].

8 Dane na podstawie strony: Budżet dla Łodzi. Tryb dostępu: http://budzet.dlalodzi.info/ [7 lipca 2017]. 
Początkowo nie wszystkie biblioteki dzielnicowe aplikowały o środki w ramach łódzkiego budżetu obywatelskiego. W I edycji złożono tylko 8 wniosków. W kolejnych edycjach liczba wniosków dotyczących łódzkich bibliotek publicznych również nie była wysoka z wyjątkiem dzielnicy Widzew, na terenie, której przygotowano 9 wniosków obywatelskich dotyczących biblioteki dzielnicowej i jej filii. Można założyć, że środki w ramach budżetu obywatelskiego realnie wpływają na funkcjonowanie łódzkich bibliotek, skoro w V edycji w 4 na 5 dzielnic Łodzi liczba wniosków bibliotecznych przekroczyła 10 . Edycja ta okazała się również rekordowa z tego względu, iż w całym mieście przygotowano aż 59 wniosków bibliotecznych.

Analizując pięciolecie funkcjonowania łódzkiego budżetu obywatelskiego należy zauważyć, że najaktywniejsi w zakresie przygotowywania wniosków dotyczących bibliotek byli mieszkańcy Bałut (43 wnioski) oraz Widzewa (38 wniosków). Łącznie zgłoszono 167 wniosków, mających na celu dofinansowanie działalności łódzkich bibliotek publicznych.

Tabela 2. Skuteczność wniosków dotyczących bibliotek, z podziałem na dzielnice miasta, złożonych do łódzkiego budżetu obywatelskiego w latach 2013-2017 (w \%)

\begin{tabular}{|c|c|c|c|c|c|c|c|}
\hline 离 & Baluty & Górna & $\begin{array}{l}\text { Śród- } \\
\text { mieście }\end{array}$ & Polesie & Widzew & $\begin{array}{l}\text { Wnioski } \\
\text { ogólno- } \\
\text { miejskie }\end{array}$ & $\begin{array}{l}\text { Lączna liczba } \\
\text { wniosków } \\
\text { skierowanych } \\
\text { do realizacji }\end{array}$ \\
\hline I & 0 & 0 & 0 & 0 & 50 & 0 & 1 z $8(12,5 \%)$ \\
\hline II & 0 & 100 & 0 & 100 & 0 & 0 & 3 z $16(18,8 \%)$ \\
\hline III & 5 & 50 & 66 & 0 & 33 & 0 & 5 z $29(17,2 \%)$ \\
\hline IV & 56 & 38 & 33 & 62,5 & 58,3 & 0 & 26 z 55 (47\%) \\
\hline $\mathrm{V}$ & $\mathrm{x}$ & $\mathrm{x}$ & $\mathrm{x}$ & $\mathrm{x}$ & $\mathrm{x}$ & $\mathrm{x}$ & $\mathrm{x}$ \\
\hline
\end{tabular}

Legenda: $\mathrm{x}$ - brak danych (głosowanie zostało zaplanowane na wrzesień 2017 r.) Źródło: opracowanie własne na podstawie strony: Budżet dla Łodzi. Tryb dostępu: http://budzet.dlalodzi.info/ [7 lipca 2017].

Aktywność w zakresie przygotowania wniosków nie jest równoznaczna $\mathrm{z}$ otrzymaniem dotacji z budżetu obywatelskiego. Przedstawiona $\mathrm{w}$ tabeli 2. w ujęciu procentowym skuteczność przygotowanych wniosków związanych z łódzkimi bibliotekami pozwala stwierdzić, że początkowo była ona 
Zbigniew GruszkA

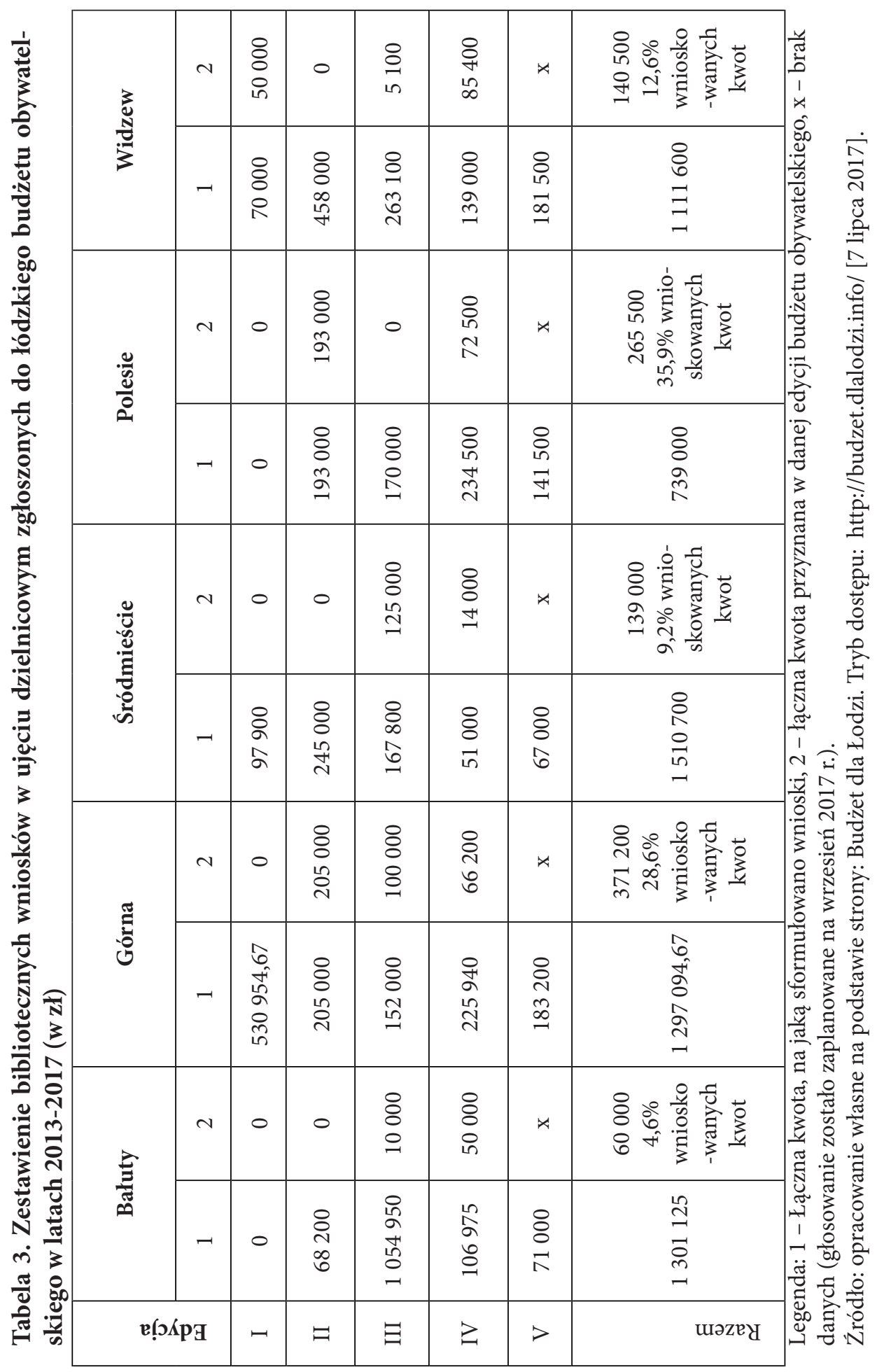


bardzo niska - w I edycji na 8 wniosków udało się doprowadzić do realizacji jeden. W II edycji z 16 wniosków - wybrane przez mieszkańców zostały trzy. Najwyższą dotychczas skuteczność w pozyskiwaniu środków obywatelskich odnotowano w IV edycji, kiedy zaakceptowano blisko połowę wniosków ( 26 z 55 zgłoszonych).

Analiza finansowa złożonych wniosków bibliotecznych w pięciu edycjach łódzkiego budżetu obywatelskiego (BO) pozwala stwierdzić dużą rozbieżność pomiędzy zgłoszonymi potrzebami, a pozyskanymi środkami. W ciągu pięciu edycji 4 na 5 bibliotek aplikowało o ponad $1 \mathrm{mln}$ zł każda (najwyższą wysokość wniosków odnotowano na terenie dzielnicy Śródmieście - 1,5 mln zł). Dotychczas najwięcej środków pozyskano w dzielnicy Polesie - na 739 tys. zł bibliotekom poleskim przyznano 265 tys. zł. Kolejną dzielnicą najskuteczniej aplikującą o środki na rzecz bibliotek była Górna, gdzie na 1,3 mln zł otrzymano 371 tys. zł. Najniższą skuteczność w pozyskaniu środków odnotowano w przypadku dzielnicy Bałuty - na 1,3 mln zł udało się pozyskać jedynie 60 tys. zł (por. tabela 3.).

Koncepcja łódzkiego budżetu obywatelskiego dopuszcza składanie wniosków ogólnomiejskich. W dotychczasowych edycjach pojawiły się 2 takie wnioski. Na kwotę $0,8 \mathrm{mln}$ zł zaplanowano zakup książek do 5 miejskich bibliotek publicznych, natomiast za 100 tys. zł planowano zrealizować regał z książkami przeznaczonymi do bookcrossingu umieszczony w centralnym punkcie miasta. Zadania nie zyskały wystarczającej liczby głosów mieszkańców, by skierować je do realizacji (tabela 4.).

Tabela 4. Zestawienie wniosków ogólnomiejskich zgłoszonych do łódzkiego budżetu obywatelskiego w latach 2013-2017 (w zl)

\begin{tabular}{|c|c|c|}
\hline \multirow{2}{*}{ Edycja } & \multicolumn{2}{|c|}{ Wnioski ogólnomiejskie } \\
\cline { 2 - 3 } & $\mathbf{1}$ & $\mathbf{2}$ \\
\hline I & 0 & 0 \\
\hline II & 800000 & 0 \\
\hline III & 0 & 0 \\
\hline IV & 100000 & 0 \\
\hline V & 0 & x \\
\hline Razem & 900000 & 0 \\
\hline
\end{tabular}

Legenda: 1 - łączna kwota, na jaką sformułowano wnioski, 2 - łączna kwota przyznana $\mathrm{w}$ danej edycji budżetu obywatelskiego, $\mathrm{x}$ - brak danych (głosowanie zostało zaplanowane na wrzesień 2017 r.).

Źródło: opracowanie własne na podstawie strony: Budżet dla Łodzi. Tryb dostępu: http://budzet.dlalodzi.info/ [7 lipca 2017]. 
Sumaryczne spojrzenie na wartość zgłoszonych wniosków dotyczących bibliotek publicznych $\mathrm{w}$ Łodzi oraz ich porównanie $\mathrm{z}$ wysokością otrzymanego dofinansowania pozwala dostrzec zmienną wysokość obywatelskiego wsparcia tych instytucji. Z pewnością I edycja nie należy do satysfakcjonujących, kiedy to ze środków partycypacyjnych skorzystała jedna filia biblioteczna. Z kolei IV edycja jest, jak na razie, najlepszą, gdy idzie o sumę pozyskanych kwot na działalność łódzkich bibliotek publicznych na 850 tys. zł, o które aplikowano, udało się zdobyć 288 tys. zł.

Łącznie należy uznać, że na pięć złotówek, o które aplikowano na rzecz bibliotek, udało się pozyskać jedną. Przez 5 lat składane wnioski urosły do kwoty blisko $6 \mathrm{mln}$ zł. Przez ten czas udało się pozyskać blisko $1 \mathrm{mln}$ zł. Należy zaznaczyć, że nierozstrzygnięta jest jeszcze edycja V łódzkiego BO, która - należy wyrazić przypuszczenie - przyniesie dalsze pozytywne rozstrzygnięcia dotyczące łódzkich bibliotek publicznych.

Tabela 5. Łączna wartość złożonych wniosków a środki przyznane w ramach budżetu obywatelskiego na działalność łódzkich bibliotek publicznych w latach 2013-2017 (w zl)

\begin{tabular}{|c|c|c|}
\hline \multirow{2}{*}{ Edycja } & \multicolumn{2}{|c|}{ Wartości dla 5 dzielnic Łodzi } \\
\cline { 2 - 3 } & $\mathbf{1}$ & $\mathbf{2}$ \\
\hline I & 698854,67 & 50000 \\
\hline II & 1969200 & 398000 \\
\hline III & 1807850 & 240100 \\
\hline IV & 857415 & 288100 \\
\hline V & 644200 & x \\
\hline Razem & 5977519,67 & $\begin{array}{c}976200 \\
16 \% \text { wnioskowanych kwot }\end{array}$ \\
\hline
\end{tabular}

Legenda: 1 - łączna kwota, na jaką sformułowano wnioski, 2 - łączna kwota przyznana $\mathrm{w}$ danej edycji budżetu obywatelskiego, $\mathrm{x}$ - brak danych (głosowanie zostało zaplanowane na wrzesień 2017 r.).

Źródło: opracowanie własne na podstawie strony: Budżet dla Łodzi. Tryb dostępu: http://budzet.dlalodzi.info/ [7 lipca 2017]. 


\section{Analiza przykładowych wniosków}

Oprócz wymagań formalnych związanych $\mathrm{z}$ zadaniami własnymi miasta nie ma w zasadzie ścisłych instrukcji, jaki rodzaj inwestycji może być przedmiotem wniosku obywatelskiego związanego z działalnością biblioteki. Analizując wyniki głosowania w rankingach dostępnych na stronach internetowych różnych miast można dostrzec, że w każdym z nich, decyzją mieszkańców, znajdują się wnioski wspierające infrastrukturę i zbiory lokalnych bibliotek publicznych. Na przykład w III edycji stołecznego budżetu partycypacyjnego identyfikujemy wnioski dotyczące zakupu książek do bibliotek i organizacji spotkań autorskich ${ }^{9}$, natomiast w Olsztynie biblioteczne wnioski zakładają stworzenie pracowni fotograficznej, cyfryzację bibliotek osiedlowych, zakup książek, audiobooków, wyposażenie bibliotek w czytniki e-booków i meble ${ }^{10}$.

W Łodzi w I edycji większość wniosków dotyczyła remontów lokali. Należy zauważyć, że w Łodzi remonty budynku bibliotecznych nie są możliwe, gdyż znaczna część budynków nie należy do miasta. Jedyny wniosek zaakceptowany w 2013 r. w I edycji dotyczył komputeryzacji i zakupu książek do Biblioteki na ul. Skalnej 2 w Łodzi i opiewał na kwotę 50 tys. zł.

W kolejnych edycjach (2014/2015 i 2015/2016) 2 na 3 składane wnioski dotyczyły zakupu książek drukowanych - zarówno do poszczególnych filii, jak i do całej sieci biblioteki dzielnicowej. W edycji 2016/2017 dotyczyło to 4 na 5 wniosków i widać tu zastanawiającą tendencję, że coraz więcej składanych do budżetu obywatelskiego wniosków polega na zakupie książek (dopiero w dalszej kolejności innych materiałów - np. audiobooków, książek z dużą czcionką). W edycji V z 2017 r. 95\% dotyczyło właśnie zakupu książek. Mimo to w niektórych wnioskach wymienione zostały potrzeby modernizacji mebli bibliotecznych, zakupu sprzętu komputerowego, biurowego i multimedialnego. Wraz z obecnymi oczekiwaniami wobec bibliotek dbałość o przestrzeń biblioteczną powinna iść równolegle $\mathrm{z}$ poszerzaniem oferty nowości i działaniami na rzecz tworzenia z łódzkich bibliotek auten-

91274 - Zakup książek i organizacja spotkań autorskich $w$ bibliotekach przy ulicy Broniewskiego 9a. Tryb dostępu: https://app.twojbudzet.um.warszawa.pl/projekt/4295 [7 lipca 2017]; 1895 - Zakup ksiażek dla Czytelni Naukowej - gospodarka, prawo, przedsiębiorczość. Tryb dostępu: https://app.twojbudzet.um.warszawa.pl/projekt/4724 [7 lipca 2017].

10 Olsztyński budżet obywatelski 2016. Tryb dostępu: http://www.mbp.olsztyn.pl/obo2016 [7 lipca 2017]. 
tycznego trzeciego miejsca - nowoczesnego i atrakcyjnego dla różnych grup społecznych.

We wnioskach do budżetu obywatelskiego dotacja na rzecz działalności biblioteki uzasadniana było następująco:

„Filia Nr 17 jest jedyną biblioteką publiczną w tej okolicy, oddaloną od innych, większa liczba nowości wydawniczych w tak oddalonej placówce byłaby wskazana, dla wygody czytelników, którzy nie musieliby dojeżdżać do innych bibliotek. Duża grupa czytelników to osoby starsze, mające problemy z poruszaniem się. Odnowione drzwi poprawią użytkowanie i estetykę wejścia do budynku. W gablocie ogłoszeniowej będą informacje o bibliotece" (IV BO, wniosek: Zakup lektur, nowości i gabloty informacyjnej, odnowienie wejścia w Filii 17, ul. Rudzka 17 na kwotę 15,2 tys. zł - skierowany do realizacji $)^{11}$.

Zwraca uwagę fakt, że niektóre placówki biblioteczne są często jednymi $\mathrm{z}$ nielicznych placówek kulturalnych $\mathrm{w}$ okolicy, a na pewno jedynymi zapewniającymi nieodpłatny dostęp do oferty. W takiej sytuacji dbałość o zakup nowości wydawniczych wydaje się niezbędna. Co ważne, we wniosku znalazł się również postulat poprawy estetyki budynku oraz zakup innych akcesoriów niezbędnych do funkcjonowania biblioteki.

Oferta łódzkich bibliotek jest także rozumiana jako ułatwienie dostępu do coraz droższych dóbr kulturalnych i przeciwdziałanie wykluczeniu społecznemu. Niestety, w przypadku poniższego wniosku nie udało się pozyskać środków na zakup nowości wydawniczych: „Zakup książek nowości wydawniczych poszukiwanych przez czytelników, mieszkańców osiedla Zarzew. Należy nadmienić, że co 18 mieszkaniec tego osiedla jest czytelnikiem Filii nr 10 MBP Łódź-Widzew. Książki są coraz droższe i nie każdego stać, zwłaszcza emeryta, na ich zakup. Realizacja projektu zwiększy atrakcyjność biblioteki, podniesie wskaźniki czytelnictwa oraz wyeliminuje obszary wykluczenia społecznego z powodu ubóstwa" (IV BO, wniosek W0017ZA: Każdy dorosty na Zarzewie znajdzie w naszej bibliotece ksiązkę dla siebie na kwotę 10 tys. zł - niezrealizowany).

Niektóre wnioski dotyczyły rozwinięcia idei trzeciego miejsca poprzez zwiększenie liczby inicjatyw oferowanych przez bibliotekę. Wniosek ten, dotyczący zakupu przede wszystkim sprzętu komputerowego i nagłośnieniowego, uzyskał akceptację i został skierowany do realizacji: „Biblioteka jako jedyna placówka kultury na Złotnie próbuje zaproponować dzie-

11 Ten i kolejne przykłady zostały zaczerpnięte ze strony: Budżet Obywatelski. Tryb dostępu: http://tablicabo.uml.lodz.pl/ [7 lipca 2017]. 
ciom, młodzieży i emerytom w wolnym czasie ciekawe zajęcia. W tym celu powinna być wyposażona $\mathrm{w}$ niezbędny sprzęt, który umożliwi prowadzenie zajęć i uatrakcyjni ofertę. Aby prowadzić warsztaty, pokazy, wyświetlać filmy, potrzebny jest aparat fotograficzny, projektor oraz laptop. Imprezy plenerowe i spotkania autorskie wymagają sprzętu nagłośnieniowego" (IV BO, wniosek P0238ZL: Doposażenie biblioteki będacej jedynym ośrodkiem kultury na Złotnie w sprzęt niezbędny przy organizacji czasu wolnego dzieciom i emerytom na kwotę 13,5 tys. zł - skierowany do realizacji).

\section{Wybrane wnioski złożone $\mathrm{w}$ V edycji lódzkiego budżetu obywatelskiego}

Podejmowane za pośrednictwem wniosków starania o fundusze dotyczą przede wszystkim zakupu książek, audiobooków, rzadziej - wykupu prenumeraty czasopism, zwłaszcza prasy codziennej ${ }^{12}$ : „Zakup nowości książkowych i audiobooków zarówno dla dzieci jak i osób dorosłych przyczyni się do lepszego funkcjonowania Filii nr $10 \mathrm{w}$ środowisku lokalnym. Ponadto placówka będzie systematycznie uzupełniała księgozbiór o lektury dla uczniów pobliskich szkół, którzy aktywnie uczestniczą w życiu biblioteki” (V BO, wniosek B0055RA: Zakup książek i audiobooków dla Filii nr 10 $M B P$ na kwotę 10 tys. zł - w toku głosowania).

W V edycji można odnaleźć również wnioski inwestycyjne: „Filia chciałaby zakupić 400-500 woluminów. Nie jest to dużo dla danej placówki, gdyż obsługuje czytelników od 0 do 100 lat. Wypożyczalnia dla dzieci i młodzieży posiada regały nieprzystosowane dla małego użytkownika. Potrzebne jest 8-10 regałów dla dzieci. Wózek biblioteczny będzie przydatny do prezentacji książek w czasie spotkań/zajęć z dziećmi w bibliotece” (V BO, wniosek G0026PK: „Kolorowa biblioteka małego człowieka". Doposażenie biblioteki i zakup książek dla Filii nr 6 MBP na kwotę 17 tys. zł - w toku głosowania).

Interesujący jest złożony $\mathrm{w} \mathrm{V}$ edycji wniosek związany $\mathrm{z}$ rozwojem w bibliotece idei trzeciego miejsca: „Chcielibyśmy stworzyć miejsce, aby kółka zainteresowań, zwykli ludzie mogli się spotykać, pogadać, podyskutować o książce, pograć w gry towarzyskie, gdzie sami mogliby zrobić sobie kawę czy herbatę. Biblioteka organizuje już spotkania różnego typu, np.

12 Przykłady wniosków pochodzą ze strony: http://tablicabo.uml.lodz.pl/, na której zamieszczono wszystkie zadania zgłoszone do V edycji łódzkiego budżetu obywatelskiego, które przeszły pozytywną weryfikację. 
Noc Bibliotek, wtedy przychodzą całe rodziny, od dziadków do prawnuków. Zestaw multimedialny, konsola przyda się młodym osobom, a i starsi na pewno spróbują swoich sił na tym sprzęcie. Dobrze, gdy biblioteka będzie lepiej przygotowana do działania" (V BO, wniosek P0150ZL: Biblio Cafe "Złotnianka” na kwotę 14,5 tys. zł - w toku głosowania).

Jak już wspomniano, głosowanie w V edycji łódzkiego budżetu obywatelskiego odbędzie się we wrześniu 2017 r. i wówczas znana będzie lista wniosków, które zdobyły największą liczbę głosów mieszkańców i zostały skierowane do realizacji.

\section{Krytyka i głosy dyskusyjne dotyczące budżetu obywatelskiego}

Oceniając liczbę zgłoszonych projektów oraz skuteczność w zakresie pozyskiwania środków pozastatutowych wspierających działalność łódzkich bibliotek publicznych można pokusić się o kilka ogólniejszych wniosków.

Zgłaszane inicjatywy biblioteczne konkurują z przedsięwzięciami remontowymi i estetycznymi proponowanymi przez mieszkańców miasta, przez co - mimo że przedstawione we właściwy sposób - przegrywają $z$ innymi inicjatywami np. o charakterze infrastrukturalnym. $Z$ tego powodu trudno w stabilny sposób projektować każdorazowo działalność biblioteki w danym roku, gdy nie wiadomo, na jakim poziomie uda się uzyskać środki z głosowania obywatelskiego w ramach budżetu partycypacyjnego. Niełatwo jest też realizować zadania biblioteczne niewątpliwie ważne dla społeczności lokalnej, lecz trudno dostrzegalne w skali całego miasta.

Idea budżetu obywatelskiego wyzwala kreatywność bibliotekarzy $\mathrm{i}$ inicjuje ich większą współpracę $\mathrm{z}$ mieszkańcami, angażuje środowisko w działania promocyjne, pozwalając dotrzeć do mieszkańców, którzy nie są czytelnikami biblioteki i przekonać ich do oddania swojego głosu na projekt biblioteczny. Budżet obywatelski daje realną szansę na pozyskanie dodatkowych - niemałych - funduszy na działalność bibliotek, przy czym trzeba zaznaczyć, że to jedna z nielicznych form wsparcia adresowanych do bibliotek publicznych, nie wymagająca wkładu własnego, trudnego do zdobycia przez wiele instytucji u progu ubiegania się o dodatkowe środki. Ponadto budżet partycypacyjny jest również szansą na wdrożenie wykraczających poza zakup książek innych innowacyjnych przedsięwzięć, zmierzających $\mathrm{w}$ stronę pełnienia przez biblioteki innych edukacyjnych i społecznych funkcji. 


\section{Podsumowanie}

Po analizie przedstawionych w artykule danych należy uznać, że łódzkie biblioteki publiczne $\mathrm{w}$ satysfakcjonującym stopniu aplikują o środki z budżetu obywatelskiego, pozyskując dotychczas 16\% z kwot, o które wystosowano wnioski. Są to jednocześnie dane przed społecznym głosowaniem w V edycji łódzkiego budżetu obywatelskiego, który - jak należy się spodziewać - umożliwi realizację bibliotekom publicznych w Łodzi kolejnych zgłoszonych inicjatyw.

Budżet obywatelski sprzyja zakupom książek, audiobooków i realizacji innych mniej kosztochłonnych inicjatyw, w zasadzie uniemożliwia natomiast realizację poważniejszych przedsięwzięć inwestycyjnych i remontowych. Aby je zrealizować, niezbędna jest pomoc organu prowadzącego, a więc Urzędu Miasta Łodzi.

Należy podkreślić, że udział łódzkich bibliotekarzy w dzieleniu środków publicznych jest dowodem na niezmienną od lat operatywność tej grupy zawodowej, oznaką jej konkurencyjności, a także - jeśli wziąć pod uwagę efektywność w pozyskiwaniu środków w wyniku głosowania obywatelskiego - świadectwem dużej roli, jaką biblioteki publiczne odgrywają w życiu mieszkańców miasta.

\section{Bibliografia}

1. 1274 -Zakup książek i organizacja spotkań autorskich $w$ bibliotekach przy ulicy Broniewskiego 9a. Tryb dostępu: https://app.twojbudzet.um.warszawa.pl/projekt/4295 [25 czerwca 2017].

2. 1895 - Zakup książek dla Czytelni Naukowej - gospodarka, prawo, przedsiębiorczość. Tryb dostępu: https://app.twojbudzet.um.warszawa.pl/projekt/4724 [7 lipca 2017].

3. Biuro ds. Partycypacji Społecznej. Tryb dostępu: http://bip.uml.lodz.pl/index. php?str=158\&id=18441 [7 lipca 2017].

4. Boryczka E.: Partycypacja społeczna. W: EkoMiasto\#Społeczeństwo: zrównoważony, inteligentny i partycypacyjny rozwój miasta. Pod red. A. Nowakowskiej, Z. Przygodzkiego, A. Rzeńcy. Łódź 2016, s. 116-136.

5. Brzeziński K.: Zaufanie społeczne a zaangażowanie obywatelskie w postprzemysłowych miastach Europy Srodkowo-Wschodniej. „Acta Universitatis Lodziensis. Folia Sociologica” Nr 52 (2015), s. 127-146.

6. Budżet dla Łodzi. Tryb dostępu: http://budzet.dlalodzi.info/ [25 czerwca 2017].

7. Co to jest budżet partycypacyjny? Tryb dostępu: http://www.twojbudzet. um.warszawa.pl/co-to-jest-bud-et-partycypacyjny [6 czerwca 2017]. 
8. Jak to działa? Tryb dostępu: http://budzet.dlalodzi.info/jak-to-dziala/ [7 lipca 2017].

9. Kalisiak-Mędelska M.: Partycypacja społeczna na poziomie lokalnym jako wymiar decentralizacji administracji publicznej w Polsce. Łódź 2015.

10. Martela B.: Budżet partycypacyjny w Polsce - wdrożenie i perspektywy. „Władza sądzenia”. 2013, nr 2, s. 23-33. Tryb dostępu: http://hdl.handle.net/11089/3752 [7 lipca 2017].

11. Olsztyński budżet obywatelski 2016. Tryb dostępu: http://www.mbp.olsztyn.pl/ obo2016. [25 czerwca 2017].

12. Stowarzyszenie Topografie. Tryb dostępu: www.topografie.pl [7 lipca 2017]. 